\section{Incorporating Nonfiction into Readers' Advisory Services}

\section{Abby Alpert \\ Guest Columnist}

Correspondence concerning this column should be addressed to

Barry Trott, Adult Services Director, Williamsburg Regional Library, 7770

Croaker Rd., Williamsburg, VA 23188;

e-mail:btrott@mail.wrl.org.Abby

Alpert is employed in the Readers' Services and Children's Services departments of the Evanston Public Library in Evanston, Illinois.
The readers' advisory world has seen a shift in the past several years from focusing exclusively on fiction reading to taking a broader view of recreational reading that includes nonfiction titles and audiobooks as well. This shift is a reflection in large part of the growing interest of readers in narrative nonfiction, as seen in the success of such works as Sebastian Junger's The Perfect Storm, Dava Sobel's Longitude, and Anna Pavord's The Tulip. Librarians are realizing that they can increase their readers' advisory services and expand their community of readers by applying the same techniques that they have used to find new titles and authors for fiction readers to working with readers of nonfiction.

In this essay, Abby Alpert examines the history of narrative nonfiction; discusses the current state of readers' advisory services for nonfiction readers, including looking at tools and techniques for working with readers; and makes some recommendations for future directions for this service.

Abby Alpert worked as a readers' advisor for the Evanston (Illinois) Public Library for nine years. She is a 2005 graduate of the Dominican University Graduate School of Library and Information Science, and is currently working part-time in Readers' Services and Children's Services for Evanston. She reviews audiovisual materials for Booklist, and is working on constructing an online readers' advisory thesaurus. She is also beginning a book on graphic novels.-Editor.

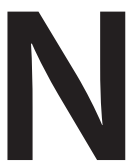

ow that the revitalization of traditional fiction readers' advisory is firmly established, publishing and reading trends require the readers' advisory community to turn its energy to expanding services to include new formats. These include graphic novels, audiovisual (AV) materials, and works of narrative nonfiction. Increasingly, nonfiction titles are being published, receiving positive critical attention, and becoming popular with the general reader. This has created both the need and the opportunity to develop readers' advisory services for nonfiction readers. This article will provide an overview of current practices in nonfiction readers' advisory, focusing primarily on narrative nonfiction, a style of nonfiction writing that adheres to the facts, but employs the literary techniques of fiction to tell a vibrant story about real events, phenomenon, people, and places. The intention is to look at the growth of narrative nonfiction, what is currently happening in nonfiction readers' advisory, and what needs to happen as narrative nonfiction is incorporated into the realm of readers' advisory services. 


\section{WHAT IS NARRATIVE NONFICTION?}

To begin with, narrative nonfiction is not a genre itself; rather it is a style that encompasses any nonfiction genre or topic that emphasizes story, including biography, memoir, and essays. Hume proposes that "somewhere between the newspaper on your doorstep and the novel on your nightstand lies narrative nonfiction." At a conference focused on narrative nonfiction hosted by Columbia University, Yare, senior editor at The Atlantic, defined it as "essentially a hybrid form, a marriage of the art of storytelling and the art of journalism-an attempt to make drama out of the observable world." He also said it "harnesses the power of facts to the techniques of fiction-constructing a central narrative, setting scenes, depicting multidimensional characters and, most important, telling the story in a compelling voice that the reader will want to hear."

There are two elements to consider in looking at this type of writing: the Narrative and the Nonfiction. The narrative requires elements that go beyond merely reporting facts or technical or expository writing. How the story is told is as significant as what happened. The strategies of fiction writing are used to recount the development of an idea, to investigate a phenomenon, or to explore a piece of history. The storytelling element necessitates scene-by-scene construction, drawing characters, finding a moving voice to communicate the drama, and conveying the facts in a way that will draw readers into the story. The Nonfiction element means that the story is based on fact, not on the realm of the imagination. The story is based on actual historical figures, political developments, institutions, objects, events, natural phenomenon, and so on; whatever the subject matter, it must have really happened. Herda aptly notes:

The key word in Narrative Nonfiction is nonfiction. Narratives must be fact. Unlike the Historical Novel that uses a real-life element as a focal point and then is fleshed out with fictional elements and characters, the Narrative Nonfiction tale starts with fact and ends with fact (and, in fact, has fact sandwiched in between). ${ }^{3}$

Basically, narrative nonfiction uses literary devices of fiction writing to take nonfiction beyond the summarization of a series of facts and into the realm of storytelling.

\section{WHY NARRATIVE NONFICTION?}

Why focus on readers' advisory for narrative nonfiction as opposed to nonfiction in general? Saricks has expanded her definition of readers' advisory in the current edition of Readers' Advisory Service in the Public Library from "service for adult fiction readers" to "service for adult leisure readers." With the increased popularity of narrative nonfiction, book publishers are seeing it as a reliable source of income. Bowker notes in its United States publishing statistics a decline in 2003 of 1.6 percent in output of fiction while nonfiction recorded "double-digit increases." Nonfiction is a growing segment of leisure reading. As Burgin states, "many users read nonfiction for pleasure and not to meet specific information needs or to conduct research." ${ }^{\prime \prime}$ A 2002 thread in Fiction_L, an active, archived readers' advisory e-mail list, was devoted to the question of including nonfiction in readers' advisory; near unanimous agreement resulted in the inclusion of nonfiction materials. ${ }^{7}$

Nonfiction library transactions have traditionally been the sphere of reference or adult services. This was based on the assumption that nonfiction titles are primarily used to gain specific information or for problem solving and are easily located by subject heading and classification number. While nonfiction collections are still composed of large numbers of informational and how-to books focused on the needs of "information people," there is a growing emphasis on putting out nonfiction for "story people." ${ }^{8}$ This is where narrative nonfiction comes in, a style of writing that tells a true story as a compelling narrative. It cuts across all categories and appeals to readers for reasons other than solely solving a problem or gaining information on a specific topic. Nonfiction titles that have been consistently popular in the past few years include Freakonomics by Steven D. Levitt, The World is Flat by Thomas L. Friedman, The Tipping Point by Malcolm Gladwell, and A Short History of Nearly Everything by Bill Bryson. Current titles that are creating a buzz are River of Doubt by Candice Millard, Team of Rivals by Doris Kearns Goodwin, and Animals in Translation by Temple Grandin and Catherine Johnson. New titles by key authors in the genre include Michael Pollan's Omnivore's Dilemma, Mark Kurlansky's The Big Oyster, Simon Winchester's A Crack at the Edge of the World, and Jared Diamond's Collapse.

Assisting patrons in searching for narrative nonfiction involves different strategies than searching for informational nonfiction. For example, in searching for informational nonfiction about childbirth, an annotated list may help a patron distinguish biases and types of information in various titles within a subject heading. If patrons wanted more titles like those written by attachment-parenting obstetrician Dr. Sears, they would search a subject heading such as natural childbirth to find additional authors such as Kitzinger. It is a fairly objective process, like searching for reference materials, where patrons know what information they are seeking and the classification system directs them to the location of materials that will meet their needs. Finding read-alikes for narrative nonfiction is a subjective skill, like suggesting fiction, and in many cases the patron may not simply want more books on a specific subject with set access points in the catalog, but rather books with similar appeal elements.

The annotations and reviews of informational nonfiction versus narrative nonfiction reflect the distinctions between them. Informational nonfiction reviews evaluate the title using such criteria as thoroughness, currency, accuracy, organization of information, ease in accessing, and indexes. These criteria reflect an emphasis on nonfiction titles that is mainly utilitarian. For narrative nonfiction, the above elements may 
also be considered, but the emphasis of the reviews and annotations is on expressing whether the book is a "good read." Does the author meld the facts into an engrossing, fun, or remarkable drama? What are the pacing, point of view, and tone? Are the storyline and characterizations compelling? All these factors - traditional appeal factors that distinguish various fiction titles from each other-are applied to nonfiction, bringing it out of the realm of straightforward information.

The following examples illustrate how readers' advisors can work with popular narrative nonfiction titles in the readers' advisory interview process.

- If a patron is looking for another book like Junger's The Perfect Storm, but not necessarily another book about shipwrecks, there is no way to search for "like" reads. The Perfect Storm crafts the specifics of an actual natural disaster into an absorbing plot with varied themes, rich characterizations, and a blend of historical and scientific details. The appeal to the reader might be in overcoming inconceivable challenges, or the man-against-nature theme, in which case Alfred Lansing's Endurance: Shackleton's Incredible Voyage or Erik Larson's Isaac's Storm might be relevant suggestions. The appeal might lie in the suspense, the thriller-like pacing, in which case Jonathan Harr's A Civil Action might be a good match.

- What if a reader enjoyed Mauve: How One Man Invented a Color that Changed the World by Simon Garfield? A key appeal element of Mauve is putting the creation of a commonplace thing in a larger context, exploring its impact, how "it changed the world." If the task was purely to find similar subject matter, one might suggest Michel Pastoureau's Blue: The History of a Color. But just as a fan of Ruth Rendell's mysteries might discard what superficially appear to be the similar psychological novels of P. D. James, a lover of Mauve might reject Blue as simply a collection of facts about a color, rather than an exploration of the history of an invention and its significance in the bigger picture. Better suggestions for a reader looking for books about small objects that created significant global ripple effects might be Zipper by Robert Friedel, the story of the "hookless fastener," Nathaniel's Nutmeg by Giles Milton, or Mark Kurlansky's Cod.

- Then there is the patron who is looking for read-alikes of James McManus's Positively Fifth Street, a journalist's absorbing account of his growing obsession with the world of competitive poker. If the appeal is in the humorous characterizations of fanatical game players or the account of intense competitive quest, Word Freak by Stefan Fatsis, a book about international Scrabble competitions, might fit the bill. If the reader's interest is in the journalist as an observer and participant or the writer's experience of becoming passionate about his subject matter, they might find Susan Orleans's The Orchid Thief a satisfying read.

Just as in an encounter with a fiction reader, suggestions for each of these nonfiction titles could go in multiple direc- tions because the potential appeals are numerous and subjective. Appeal extends beyond subject headings and varies from patron to patron, requiring the application of readers' advisory strategies to clarify the compelling facets of a book and base relevant reading suggestions on those appeals.

\section{HISTORY OF NARRATIVE NONFICTION}

Narrative nonfiction is relatively new and its history reveals much about the style. One of the most curious elements is that important novelists of the eighteenth and nineteenth centuries such as Daniel Defoe, Charles Dickens, Henry Fielding, Leo Tolstoy, and William Makepeace Thackeray all used nonfiction to build fictional accounts. Their novels were based on detailed realism about people and events of their day. Beginning in the mid-1900s, fiction moved away from social realism toward the experimental, the imaginary, and the spiritual. Looking at nonfiction bestseller lists, which began in 1912, it is evident that through the 1950s, "most of nonfiction continued to represent an America involved in home, family, and looking good." $\mathrm{A}$ focus on childrearing, self-help, celebrity books, cookbooks, diet, and etiquette continues, but a new trend began to emerge in the 1960s pioneered by writers including Tom Wolfe, Gay Talese, and Hunter S. Thompson. Called "literary journalism," "fact writing," or "the new journalism," it was a style that used literary technique to endow journalistic reporting with drama and emotional impact.

This new journalistic style was an obvious precursor of narrative nonfiction. Applegate notes that it was a "form of writing that combines the literary devices of fiction with the journalistic techniques of nonfiction." ${ }^{10}$ Journalists began to add creative elements, inner points of view, and fictional devices such as scenes, dialogue, and descriptive embellishment. Much of the new journalism dealt with political and social issues, indicating that the change in focus was perhaps related to the complexity of societal changes in the 1960s. As reality became stranger than fiction, journalists filled a gap, left by novelists, by going beyond simple reporting towards an attempt to make sense of current events. Talese said the goal of "new journalism" was "to seek a larger truth than is possible through mere compilation of facts." 11

During this period in time, novelists such as Norman Mailer, Joan Didion, and Truman Capote began to turn toward nonfiction subject matter in works termed the "true life novel," "faction novel," and the "nonfiction novel." In 1966, Capote wrote In Cold Blood, originating contemporary, booklength narrative nonfiction and the genre of True Crime in general. In an interview with Frankel, Capote said that he "got this idea of doing a really serious big work-it would be precisely like a novel, with a single difference: every word of it would be true from beginning to end." ${ }^{\prime 2}$ Other notable narrative nonfiction titles written in the 1960s and 1970s include Jessica Mitford's The American Way of Death, Carl Bernstein and Bob Woodward's All the President's Men, and Tom Wolfe's The Right Stuff. 


\section{READERS' ADVISORY}

In the 1980s, questions were asked about the differences between factual and fictional narratives and whether those lines were becoming obscured. The use of composite characters and reconstructed dialogue that had not been recorded were particularly questionable techniques, creating debate over if and when the new nonfiction entered the realm of "faction," a term coined by Alex Haley, describing the gray zone between fact and imagination. As a result, the provocative, dramatic nonfiction that was produced through the 1980s moved from a first-person journalistic perspective to straight narrative nonfiction such as, Tracy Kidder's works, The Soul of a New Machine and House or the best-selling Brief History of Time by Stephen W. Hawking. Also in the 1980s, the New York Times Book Review separated its nonfiction paperback bestseller lists into two lists: "Advice, How-to, and Miscellaneous" and general "Nonfiction," making room for narrative nonfiction titles and thereby increasing recognition and sales.

In the 1990s, narrative nonfiction really took off and became a hugely successful publishing trend. Two titles that met with critical and popular success began a gold rush for narrative nonfiction titles. John Berendt's Midnight in the Garden of Good and Evil sold more than 2.5 million copies, was a finalist for the Pulitzer Prize in 1995, and spent an unprecedented five years on the New York Times bestseller list, a feat previously unheard of for any fiction or nonfiction title. In 1994, magazine writer Dava Sobel was contracted by Walker publisher George Gibson to turn a magazine article about the man who invented the chronometer into a book. The result was Longitude, published in 1995, which spent eighteen weeks on the New York Times bestseller list and began the popularity of a new history subgenre most often called the Microhistory. The 1990s also saw resurgence in popularity of narrative nonfiction genres of memoir and essays, often referred to as "creative nonfiction" in these genres. Confessional or inspirational memoirs such as Angela's Ashes (Frank McCourt), The Liar's Club (Mary Karr), and Tuesdays with Morrie (Mitch Albom) spawned a wide readership, initiating what has been termed the "self-revelation industry," a hot subgenre in narrative nonfiction. Other benchmark titles from the late 1990s and early 2000s include The Professor and the Madman (Simon Winchester), Black Hawk Down (Mark Bowden), Into Thin Air (Jon Krakauer), Seabiscuit (Laura Hillenbrand), Fast Food Nation (Eric Schlosser), and Devil in the White City (Erik Larson).

The continuing popularity of titles such as these has proven to publishers that narrative nonfiction is not an ephemeral fad and that it sells. As a result, nonfiction titles are now enjoying big print runs, publicity campaigns, and critical acclaim. The increasing readership of narrative nonfiction has lead to the pronouncement by William Zinsser, former editor of the Book of the Month club, that nonfiction is "the new American literature." ${ }^{13} \mathrm{An}$ interesting note on the circularity of movements: increasingly we are seeing novelists, riding on the wave of nonfiction's present "golden age," writing fiction that reads like the new nonfiction, bringing us full circle to the eighteenth- and nineteenth-century novelists who based their novels on actual events. Examples include Peter Carey's
True History of the Kelly Gang, Claire Clarke's Victorian murder mystery The Great Stink, and The Known World by Edward P. Jones. The popularity of this "new American literature" necessitates the same kind of attention and techniques that the Readers' Advisory community has given to genre fiction. Categorization of narrative nonfiction by genres and subgenres and delineation of the characteristics and appeals of narrative nonfiction are basic requirements for providing quality readers' advisory services.

\section{CATEGORIZATION BY GENRE AND SUBGENRE}

The first step in providing nonfiction readers' advisory, one that is currently being addressed, is identifying and defining the popular characteristics of the various nonfiction genres and subgenres. Grouping narrative nonfiction books implies that one can know what to expect from a book in a particular genre, and will assist in the process of finding similar titles. As Saricks writes, "We're going to have to figure out what the most useful categories of nonfiction are and which authors exemplify them."14 In looking at a variety of genre breakdowns, including Saricks's popular nonfiction list, Novak's and Rubie's lists, and various nonfiction Web sites, many of the genres overlap, while others are specific to the author. ${ }^{15}$ The following genres appear to be commonly listed, noted with varying names:

- Biography/Autobiography, Memoirs, Diaries

- Essays/Short True Stories/Reflections

- Humor

- Travelogues/Travel Books/Books with a Strong Sense of Place

- Survival/Disaster/Exploration/Adventure/Man against Nature

- Animal/Natural History/Nature Writing

- Science/Technology and Inventions

- Medicine/True Medical Accounts/Medicine and Psychology

- Overcoming Adversity/Self-Help/Inspirational

- Business/Personal Finance

- Life Style/Popular Culture/Entertainment

- Religion

- Sports

- True Crime

- History/Microhistory/Military

- Contemporary Issues/Journalistic Reportage/ Exposés/Current Affairs/Politics

One of the difficulties in the categorization process is that many narrative nonfiction books are hybrids. For instance, Adventure titles often combine elements of Travel writing, Memoir, Man against Nature, and Overcoming Adversity genres. Some see Military books, often hybrids of history and biography, as a genre of its own while others regard it as a subset of history. Microhistory, a type of history very narrow in subject matter but comprehensive and multidisciplinary in 
coverage is currently an extremely popular type of narrative nonfiction that supplies a good example of the challenges of categorizing nonfiction genres. A Microhistory may be a subgenre of History or a genre in its own right. The popularity and therefore publication output of Microhistories has been prolific enough to divide it into subgenres of its own, including possibilities such as "concept histories," which illustrate the story of an idea, "material histories" or "case studies," which track an arcane object, or "slices of history," which offer accounts of discrete historical events.

Another example of the challenge of defining subgenres can be seen with three differing models of categorizing True Crime. The first model is from www.bloodpage.com, a Web site that divides true crime into sixteen subgenres, including Serial Killers, Organized Crime, and Historical Crime. The second is more manageable, from a handout at a readers' advisory workshop, divided into eleven subgenres with titles such as "Bad Boys, Bad Boys," "All in the Family," and "Mind Probe."16 Or perhaps a simpler, more useful approach is dividing it into two subgenres as offered by Charles Spicer, editor of St. Martin's Press True Crime Library series: Gut Stories-those that affect readers on a primal level, and Glamour Stories-those set in the world of the rich and famous. ${ }^{17}$

The nonfiction readers' advisory program at the 2005 American Library Association (ALA) Annual Conference in Chicago included a categorization developed by Reference and User Services Association (RUSA)/CODES Readers' Advisory Committee identifying fifteen genres of narrative nonfiction and annotating the benchmark titles in each genre (www.ala .org/ala/rusa/rusaourassoc/rusasections/codes/codessection/ codescomm/codesreadadv/readersadvisory.htm). In addition, the Genreflecting Web site, www.genreflecting.com, a useful readers' advisory tool that divides works of fiction by genre, has a "Recreational Nonfiction" site under construction.

\section{CHARACTERISTICS AND APPEAL}

As nonfiction categories become defined, specific characteristics for individual genres and subgenres will be assigned. What follows are some general characteristics of the narrative nonfiction style. Lounsberry lists four that are a useful start. Narrative nonfiction must have: Documentable Subject Matter, Exhaustive Research, the Scene, and Fine Writing. ${ }^{18}$ Two additional characteristics are Style, which includes Fine Writing and Theme.

1. Documentable Subject Matter: Narrative nonfiction must be based on fact; it is not invented or from the realm of the imagination. It must be about such things as actual people, events, social issues, institutions, or natural phenomenon. All material must be documentable and not from the author's imagination. Learning about things that really happened is an important appeal element for narrative nonfiction readers.

2. Exhaustive research: Narrative Nonfiction requires the authors to have immersed themselves in their subject matter; to thoroughly accumulate detail, accurately research setting, carefully interview all the principles in order to reconstruct events, and dialogue correctly (both spoken and interior monologue). Eichenwald writes, "every fact-from the weather conditions, to the color of the wallpaper, to the types of meals eaten by the characters-has to come from somewhere. ${ }^{19}$ Created dialogue or quotes and composite characters are reasons for readers to reject a work of narrative nonfiction. Verifiable references and authenticity are critical both to the integrity of the narrative and to establish trust with the reader.

3. The Scene: This characteristic encompasses the storytelling aspect: scenes supply strong narrative drive, "an arc that builds to a climax."20 Fiction techniques such as strong construction of scenes and realistic dialogue, welldrawn characterizations, and point-of-view must be present to carry the narrative, relaying the facts in the form of a compelling story and providing drama and depth to draw the reader in. Rubie describes the application of narrative to nonfiction in an interesting way: "Truth becomes refracted, like a light through a prism, and becomes something other, although still the truth." ${ }^{21}$

4. Style: Style refers to the quality of the writing. Narrative nonfiction has a literary prose style that goes beyond the functional writing of informational nonfiction. It also refers to voice, an element of style that provides subtext and meaning. Possible tones include comic, solemn, ironic, or optimistic, each eliciting a variety of potential reader responses. Author's voice layers a personal, emotional quality onto a factual account. The title of a 1966 article about the new journalism expressed this combination fittingly: "The Personal Voice and the Impersonal Eye."22 Personal voice and literary prose are stylistic techniques that separate narrative nonfiction titles from general nonfiction. According to Anderson, "Our experience of reading contemporary nonfiction is an experience of style."23

5. Themes: All narrative nonfiction has themes and often the genre determines the broad range of themes dealt with. Common themes include examinations and revelations about our society today, lessons from the events of the past, showing how an event or item impacted history or society, or illustrating how people overcame challenges or succeeded in huge undertakings.

Saricks and Brown identify four elements of appeal for fiction: pacing, characterization, story line, and frame. ${ }^{24}$ Pearl presents the additional element of language. ${ }^{25}$ In terms of the appeals of narrative nonfiction, as Shearer writes, "the list of appeal factors of fiction identified in the readers' advisory literature overlaps the appeal factors of nonfiction but omits many factors of importance to readers of nonfiction." ${ }^{26}$

What are some of the appeals that are unique to nonfiction? The first is that people are enjoying a good story while at the same time learning something about real events, people, or places. As Wolfe notes of literary journalism, it "enjoys an advantage so obvious, so built in, one almost forgets what a 


\section{READERS' ADVISORY}

power it has: the simple fact that the reader knows all this actually happened." ${ }^{27}$ Carr writes, "Nonfiction is crafted to communicate accurate images to the reader, so that the reader might in turn craft more complex understandings of lived experiences." ${ }^{28}$ Novak also suggests the appeal of learning from other's experiences, whether from celebrities and heroes or from the average person. ${ }^{29}$ Rubie mentions that these books take an "incident and pry it apart, searching for a way to understand, in the microcosm of the story, more about the macrocosm of our world-who we are and why we do the things we do-while at the same time giving us a rattling good yarn." 30

These aspects of narrative nonfiction potentially result in propelling the readers into a social, political, or historical dialogue. Narrative nonfiction is more than straight reportage; it goes beyond objective information as a result of the author's subjective voice telling a true story. Therefore, it may appeal because it can motivate change, shape outlook, or instigate action. A further appeal of narrative nonfiction may be in its intellectual content: learning about how an object or discovery shaped human history or the achievement of understanding a complex topic that has been expressed in an accessible and pleasurable fashion. This is especially apparent in narrative nonfiction accounts that take an outwardly dull piece of history or a dry math topic and create an exciting page-turner from it. Additional appeal factors that are specific to nonfiction include level of scholarship, depth and documentation of research, and the aesthetics of the physical book, including maps, illustrations, and index. During a nonfiction readers' advisory interview, the readers' advisor must keep in mind both the basic fiction appeals in addition to determining the nonfiction appeal elements. Nonfiction appeals are not a finite group of elements and can vary extensively. Establishing the appeal-what hooks the nonfiction reader-is the first step in developing effective nonfiction readers' advisory.

\section{TOOLS FOR NARRATIVE NONFICTION READERS' ADVISORY}

The next step in developing successful nonfiction readers' advisory transactions is providing the tools and the resources for readers' advisors to find relevant nonfiction reading based on reader preferences. This process is in its infancy at this point in time. Some of the common resources that readers' advisors have been using include bestseller lists and reviews of new and forthcoming nonfiction titles in basic collection-development review sources such as Booklist, Library Journal, and Publishers Weekly. Newspaper review sections, particularly the New York Times Book Review, devote an increasing amount of space to nonfiction titles. Burgin and others are fond of Amazon.com as a helpful tool in finding similar nonfiction titles of interest from reader-review suggestions, other books purchased, and the Listmania feature. Barnesandnoble.com offers similar features, and its Bookbrowser.com site presents the option of searching books with related themes and sub- jects. The following is a selected list of useful Web sites for nonfiction readers' advisory:

- All Readers (www.allreaders.com). Provides Biography and History read-alikes through searching by subgenre and some appeals elements

- Book Bytes (www.marylaine.com/bookbyte/real1 .html). Recommendations and reviews of many nonfiction titles by librarian and book reviewer Marylaine Block

- Book TV (www.booktv.org). Complements BookTV weekend programming on C-SPAN 2, which covers nonfiction books. This Web site provides an opportunity to watch or listen to the programs and supplies additional information not available on the network.

- CODES Readers' Advisory Committee (www.ala .org/ala/rusa/rusaourassoc/rusasections/codes/codes section/codescomm/codesreadadv/readersadvisory .htm). Links to handouts of nonfiction genre classifications, benchmark works, and appeal elements of each genre

- Entertaining Nonfiction (www.picnet.org/booklovers/ nonfiction.aspx?menu=booklovers). Numerous annotated lists of nonfiction titles from the Pickering (Ont.) Public Library

- Fourth Genre (http://msupress.msu.edu/journals/ fg). Explorations in nonfiction; issues include many book reviews and other interesting material on narrative nonfiction

- If You Like . . . (http://library.christchurch.org.nz/ Guides/IfYouLike/\#biographies). Popular "If you like ." site that provides read-alikes for Nonfiction and Biography

- If You Like ... Nonfiction (www.hclib.org/pub/books/ iyl/ifyoulikeNF.cfm). Hennepin County (Minn.) Library's popular site provides extensive, well-annotated lists for "if you liked ... nonfiction" on a variety of topics

- Nonfiction that Reads Like Fiction (www .waterborolibrary.org/bklistnonf.htm). An excellent collection of nonfiction reading lists compiled by Molly Williams at the Waterboro (Maine) Public Library

- The Reader's Advisor (http://sachem.suffolk.lib.ny.us/ advisor/advisor.htm). Sachem (N.Y.) Public Library provides a great selection of topical nonfiction lists

- The Reader's Club (www.readersclub.org/category .asp?cat=2). Reviews of titles in many nonfiction genres written by library staff at the Public Library of Charlotte and Mecklenburg County, North Carolina.

Other sources of information include publisher's catalogs-for instance, McGraw-Hill, which publishes approximately six hundred nonfiction books yearly and has a nonfiction backlist of six thousand. ${ }^{31}$ Narrative nonfiction book lists are easily searched on Google by typing in "nonfiction that reads like fiction" or for specific popular titles, read-alike lists can be searched by typing in (for example) "if you liked into thin air." Fiction_L, www.webrary.org/rs/flmenu.html, 
composed its first list of "nonfiction that reads like fiction" in 1998 and added an updated list in 2003. An additional resource for readers' advisors is nonfiction award-winner lists, including the following prizes:

- American Booksellers Association Award (www .bookhelpweb.com/awards/aba/aba.htm)

- Audie Award for Nonfiction Audiobook (www .writerswrite.com/books/awards/audie.htm)

- Aventis Prize for Science Books (www.aventisprizes .com/about_prevwinn.htm)

- Lionel Gelber Prize (www.utoronto.ca/mcis/gelber/ Winners.shtml)

- Lukas Prize Project (www.jrn.columbia.edu/events/ lukas/winners)

- National Book Critics Circle (www.literatureawards. com/national_book_critics_circle.htm)

- Pulitzer Prize nonfiction (www.pulitzer.org/index .html)

- Samuel Johnson Prize (www.bbc.co.uk/bbcfour/books/ features/samueljohnson/)

Reference materials and training resources for working with nonfiction readers are also currently being produced. Last year, Libraries Unlimited published the first readers' advisory reference book on nonfiction, Nonfiction Reader's Advisory, a collection of essays from scholars and practitioners. Greenwood just published The Real Story in their Genreflecting Advisory Series that contains five hundred nonfiction titles with read-alikes. ALA Editions has a nonfiction readers' advisory title under contract, and one can hope that What Do I Read Next? will also publish useful titles. Nonfiction workshops and programs are increasingly seen at major conferences, including programs at the 2004 and 2005 ALA Annual Conferences, and the 2004, 2005, and 2006 Public Library Association conferences. Recent programs have included readers' advisory for historical fiction and history and a new technique called the reader's map that blends fiction and nonfiction titles by theme or subject. These workshops and resources greatly assist readers' advisors in providing adequate services to nonfiction leisure readers.

Here are some tips for promoting nonfiction titles in the public library. Booklists and bookmarks are effective ways to increase circulation of titles. Displays are also popular and the opportunities for nonfiction displays are many; seasonal themes, local exhibit and event tie-ins, and staff recommendations tend to be popular. All these displays could work mixing fiction and nonfiction also. Another avenue for promoting nonfiction reading is book discussion groups, by mixing nonfiction titles into a primarily fiction group, or creating a nonfiction-only group, an option that has the bonus of being a draw to attract men to library programs. Publisher-produced reading guides for nonfiction can often be found online (for example, see www.harpercollins.com/readers.asp and www .readinggroupguides.com/findaguide/biography_memoir.asp for guides of popular biographies and memoirs). Books about organizing discussion groups often address nonfiction book groups. For instance, Good Books Lately devotes sections to nonfiction, to memoir, and to biography. ${ }^{32} \mathrm{~A}$ useful source of ideas for marketing nonfiction is Fiction_L, which has archived threads on book groups, resources, booktalking, booklists, and displays for nonfiction titles. Most methods of marketing books are applicable in incorporating narrative nonfiction into library services.

Readers' advisory is essentially about suggesting titles that will suit our users' pleasure-reading needs and tastes. Narrative nonfiction, an innovative and increasingly popular category of adult leisure reading, forces us to broaden our concept of readers' advisory and presents an exciting challenge to readers' advisors to expand the scope of our knowledge and services. It is imperative to the vitality of our service that training, tools, and resources for nonfiction readers' advisory continue to be developed so that readers' advisors can become familiar with the wide range of appeal factors and titles that allow them to connect nonfiction "story people" with pleasing and satisfying reads.

\section{References}

1. Edward Humes, "Literary Nonfiction-Walking the Line," www californiaauthors.com (accessed Oct. 27, 2004).

2. Robert Vare, "The State of Narrative Nonfiction Writing," Nieman Reports 54 (Fall 2000): 18

3. D. J. Herda, "Writing the Narrative Nonfiction Book," The Writers Lounge, www.writerslounge.org/0104-writingtips-Narrative Nonfiction.html (accessed Oct. 27, 2004).

4. Joyce G. Saricks, Readers' Advisory in the Public Library, 3rd ed. (Chicago: ALA, 2005).

5. Bowker Press Release, May 27, 2004, www.bowker.com/press/ 2004_0527_bowker.htm (accessed Oct. 27, 2004).

6. Robert Burgin, "Readers' Advisory and Nonfiction," in The Readers' Advisor's Companion, eds. Kenneth D. Shearer and Robert Burgin (Englewood, Colo.: Libraries Unlimited, 2001), 213.

7. Fiction_L thread, May 8, 2002 through July 29, 2002, www .webrary.org/maillist/ msg/2002/5/Re.NonfictionRA.html (accessed Oct. 20, 2004)

8. Bill Ott, "Story People," Booklist 94 (Sept. 1, 1997): 4.

9. Michael Korda, Making the List: A Cultural History of the American Bestseller, 1900-1999 (New York: Barnes \& Noble, 2001), 100

10. Edd Applegate, Literary Journalism: A Biographical Dictionary of Writers and Editors (Westport, Conn.: Greenwood, 1996), preface.

11. Peter Rubie, Telling the Story: How to Write and Sell Narrative Nonfiction (New York: Quill, 2003), 4.

12. Haskel Frankel, "The Author," Saturday Review 49 (Jan. 22, 1966): 37.

13. Barbara Lounsberry, The Art of Fact: Contemporary Artists of Nonfiction (New York: Greenwood, 1990), xvi.

14. Joyce Saricks, "Not Just Fiction," Booklist 101 (Sept. 1, 2004): 56.

15. Saricks, Readers' Advisory in the Public Library; Vicki Novak, "The Story's the Thing: Narrative Nonfiction for Recreational Reading," in Nonfiction Reader's Advisory (Westport, Conn.: Libraries Unlimited, 2004), 219-22; Rubie, Telling the Story, 20-27.

16. Outagamie Waupaca Library System, "Nonfiction Readers' Advisory Workshop," www.owls.lib.wi.us/ce/handouts/2004/ NonFictionURLS.pdf (accessed Nov. 24, 2004).

17. Gerald Gross, Editors on Editing: What Writers Need to Know about What Editors Do (New York: Grove, 1993).

18. Lounsberry, The Art of Fact, xiii-xv. 


\section{READERS' ADVISORY}

19. Kurt Eichenwald, "Rewriting the Rules of Nonfiction," www .booksense.com/people/archive/eichenwald.jsp (accessed Oct. 27, 2004).

20. Sandra Lamb, "Narrative Nonfiction," Writer 117 (May 2004): 45-46.

21. Rubie, Telling the Story, 16.

22. Dan Wakefield, "The Personal Voice and the Impersonal Eye," Atlantic 217 (June 1966): 86-90.

23. Christopher Anderson, Style as Argument: Contemporary American Nonfiction (Carbondale: Southern Illinois Univ. Pr., 1987), 1.

24. Joyce G. Saricks and Nancy Brown, Readers' Advisory Service in the Public Library, 2nd ed. (Chicago: ALA, 1997).

25. Nancy Pearl, Now Read This: A Guide to Mainstream Fiction, 1978-1998 (Englewood, Colo.: Libraries Unlimited, 1999); Nancy Pearl, Now Read This II: A Guide to Mainstream Fiction, 1990-2001 (Englewood, Colo.: Libraries Unlimited, 2002).

26. Kenneth D. Shearer, "The Appeal of Nonfiction: A Tale of Many Tastes," in Nonfiction Readers' Advisory (Westport, Conn.: Libraries Unlimited, 2004), 69

27. Tom Wolfe, ed., The New Journalism (New York: Harper, 1973), 34.

28. David Carr, "Many Kinds of Crafted Truths: An Introduction to Nonfiction," in Nonfiction Reader's Advisory (Westport, Conn.: Libraries Unlimited, 2004), 50.

29. Novak, "The Story's the Thing."

30. Rubie, Telling the Story, 2-3.

31. Jim Milliot, "McGraw-Hill Carves Place in Nonfiction," Publishers Weekly 250 (June 16, 2003): 16

32. Ellen Moore and Kira Stevens, Good Books Lately: The One-Stop Resource for Book Groups and Other Greedy Readers (New York: St. Martin's Griffin, 2004).

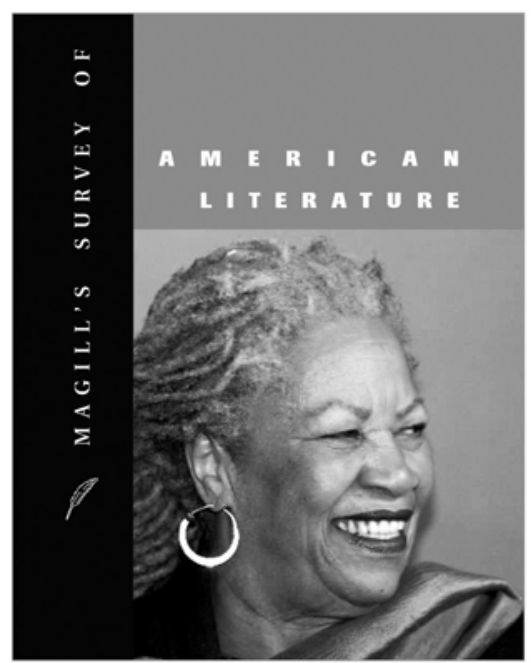

\section{Magill's Survey of American Literature}

Profiles of 340 writers at the heart of literary studies, accompanied by career analysis as well as critiques of individual titles.

The Survey was originally published in 1991 to widespread critical acclaim. This revised edition updates and adds to the remarkable original. Fiction, drama, poetry and nonfiction are all included. A number of Canadian authors have been added and there are more minority and women writers included. Authors of young adult fiction are also represented.

September 2006

6 volumes; 2,600 Pages ISBN: 1-58765-285-4

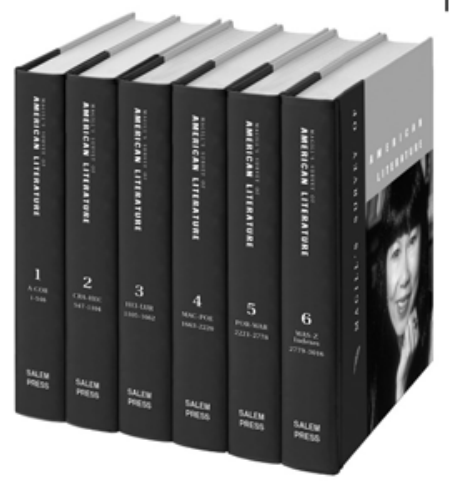

LIST PRICE: \$499

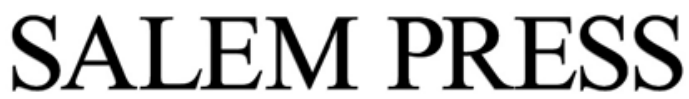

(800) 221-1592 • www.salempress.com 